\title{
The B-cell Compartment in the Peripheral Blood of Children With Different Types of Primary Humoral Immunodeficiency
}

\author{
KAROLINA BUKOWSKA-STRAKOVÁ, DANUTA KOWALCZYK, JAROSŁAW BARAN, MACIEJ SIEDLAR, \\ KRZYSZTOF KOBYLARZ, AND MAREK ZEMBALA
}

\author{
Departments of Clinical Immunology [K.B.-S., D.K., J.B., M.S., M.Z.] and Anesthesiology and Intensive Care [K.K.], Jagiellonian \\ University Medical College, Cracow 30-663, Poland
}

\begin{abstract}
The aim of this study was to evaluate the B-cell compartment in the peripheral blood of children with different types of hipogammaglobulinemia: common variable immunodeficiency (CVID), transient hypogammaglobulinemia of infancy (THI), and selective IgA deficiency (SIgAD). We analyzed by flow cytometry the changes in the B-cell subsets with age and showed that children with an early-onset CVID develop similar pattern of B-cell subsets as adult patients with CVID with age, as the levels of memory B cells $\left(\mathrm{CD} 19^{+} / \mathrm{CD} 27^{+}\right)$and class-switched memory B cells $\left(\mathrm{CD} 19^{+} /\right.$ $\mathrm{CD} 27^{+} / \mathrm{IgD}^{-} / \mathrm{IgM}^{-}$), in contrast to age-matched control group, did not increase with age. Children with SIgAD displayed similar changes as patients with CVID only within the class-switched memory B-cell subpopulation. No significant differences in the level of memory B cells and class-switched memory B cells in children with THI in comparison to age-matched control group were observed. There were no differences in the percentage of immature B cells $\left(\mathrm{CD} 19^{+} / \mathrm{CD} 21^{\text {low }}\right)$ among all studied groups. As B-cell subsets in children with THI were normal during entire period of hypogammaglobulinemia, the persistence of low levels of memory B-cell subsets in some children may facilitate the diagnosis of CVID. (Pediatr Res 66: 28-34, 2009)
\end{abstract}

$\mathrm{T}$ The pathogenesis of some primary humoral immunodeficiencies with the presence of circulating B cells remains unknown and frequently causes diagnostic difficulties. Common variable immunodeficiency (CVID) is a heterogeneous, poorly defined disorder characterized by low serum levels of $\mathrm{IgG}$ and usually $\operatorname{IgA}$ or IgM. Common clinical picture may result from multiple mechanisms. A failure of T-cell and B-cell cooperation, primary T-cell defects (1-3), excessive T-cell suppression (4), polarization toward Th1 response (5), or primary B-cell defects $(6,7)$ have been reported. In some patients with CVID, defects in B-cell receptors signaling and B cell development have been described, especially mutations in $C D 19$ (8), B-cell activating factor of the tumor necrosis factor family receptor $(B A F F-R)(9)$, inducible costimulator of activated T cells (ICOS) (10), and transmembrane activator and CAML interactor (TACI) (11-14), which are required for maturation of B cells and generation of antibody diversity. Disease is usually diagnosed in the second or third decade of life after a history of recurrent pyogenic sinopulmonary infec-

Received October 14, 2008; accepted February 18, 2009.

Correspondence: Karolina Bukowska-Straková, M.Sc., Department of Clinical Immunology, Polish-American Institute of Pediatrics, Jagiellonian University Medical College, Wielicka Str. 265, 30-663 Cracow, Poland; e-mail: karobuko@ poczta.onet.pl

Supported by the State Research Committee (grant no 3 PO5E 039 23). tions (15), but some cases of CVID are diagnosed in the childhood as an early-onset CVID.

Selective $\operatorname{Ig}$ A deficiency (SIgAD) is the most prevalent primary humoral immunodeficiency. The clinical picture of SIgAD may vary from absence of clinical manifestations to fully symptomatic form (16). A variety of pathologic mechanisms of SIgAD have been postulated, which include the occurrence of IgA-specific $\mathrm{T}$ suppressor cells, inadequate $\mathrm{T}$ helper (Th) cell function, an intrinsic B-cell defects (17), or decreased expression of CD40 on monocytes (18). In most cases, the molecular defect is unknown, although in some patients with SIgAD, mutations in TACI gene have been identified $(11,12)$. SIgAD is considered to be genetically linked with CVID, as the latter may develop from SIgAD (19-21) and occasionally vice versa (22). Familial studies have implicated the existence of an allelic relationship between SIgAD and CVID, indicating that these disorders have the same molecular defect (23).

Transient hypogammaglobulinemia of infancy (THI) is defined by decreased level of IgG (below 2 SD for the agematched healthy children) and in some cases low level of $\operatorname{Ig} \mathrm{A}$ and intact cell-mediated immunity. Production of antibodies after immunization is normal and IgG level normalizes with age (5). Etiology of THI remains unknown.

Because of heterogeneity of CVID, several classifying schemes have been developed. The most popular schemes are based on the B-cell phenotype in the peripheral blood (2426). The B-cell compartment in the peripheral blood is composed of naive $\mathrm{B}$ cells $\left(\mathrm{CD} 19^{+} / \mathrm{CD}^{2} 7^{-} / \mathrm{IgD}^{+} / \mathrm{IgM}^{+}\right)$, memory $\mathrm{B}$ cells $\left(\mathrm{CD} 19^{+} / \mathrm{CD} 27^{+}\right)$immature $\mathrm{CD} 19^{+} / \mathrm{CD} 21^{\text {low }} \mathrm{B}$ cells, transitional $\mathrm{B}$ cells $\left(\mathrm{CD} 19^{+} / \mathrm{CD} 38^{\text {high }} / \mathrm{IgM}^{\text {high }}\right)$, and classswitched plasmablasts $\left(\mathrm{CD} 19^{+} / \mathrm{CD} 38^{+++} / \mathrm{IgM}^{-}\right)$(26). On encountering antigen, naive $\mathrm{B}$ cells $\mathrm{CD} 19^{+} / \mathrm{CD} 27^{-} / \mathrm{IgD}^{+} /$ $\mathrm{IgM}^{+}$enter germinal centers where they undergo isotype class-switch recombination and somatic hypermutation and, ultimately, develop into plasma or memory B cells $\left(\mathrm{CD} 19^{+} /\right.$ $\mathrm{CD} 27^{+}$) (27). Memory B cells can be further subdivided into marginal zone $\mathrm{B}$ cells $\left(\mathrm{CD} 19^{+} / \mathrm{CD} 27^{+} / \mathrm{IgM}^{+} / \mathrm{IgD}^{+}\right)$and class-switched memory B cells $\left(\mathrm{CD} 19^{+} / \mathrm{CD}^{2} 7^{+} / \mathrm{IgM}^{-} / \mathrm{IgD}^{-}\right)$

Abbreviations: CVID, common variable immunodeficiency; PBMCs, peripheral blood mononuclear cells; SIgAD, selective IgA Deficiency; TACI, transmembrane activator and CAML interactor; THI, transient hypogammaglobulinemia of infancy 
$(28,29)$. Marginal zone B cells undergo limited somatic hypermutation and produce high-affinity $\operatorname{IgM}$ and some $\operatorname{IgG}$, whereas class-switched memory B-cells synthetize IgG, IgM, and $\operatorname{IgA}(28)$. Marginal zone B cells $\left(\mathrm{CD} 19^{+} / \mathrm{CD} 27^{+} / \mathrm{IgM}^{+} /\right.$ $\mathrm{IgD}^{+}$) in the blood represent recirculating splenic marginal zone B-cell population $(30,31)$. In most adult patients with CVID, mature B cells are present in normal numbers (32) but the development of memory B cells is disturbed (33). Phenotypic analysis of B-cell subsets revealed reduction of memory $\mathrm{CD} 27^{+}$and class-switched memory B cells, as a hallmark of the immunologic phenotype in patients with CVID (33-36), and increase in the number of immature $\mathrm{CD} 21^{\text {low }} \mathrm{B}$ cells. Based on a B-cell phenotype, the most commonly used CVID classifications are the Paris (24), the Freiburg (25), and the EUROclass (26). Classification schemes of patients with CVID and reference values of B-cell subsets are established mainly in adults. Because of the fact that levels of B-cell subsets are age-dependent parameters, they need to be analyzed according to the appropriate age-matched control groups.

In this study, analysis of B-cell subsets in the peripheral blood of children with CVID, SIgAD, and THI and a comparison with an appropriate age-matched control was performed. The following subpopulations of B cells were determined: memory B $\left(\mathrm{CD} 19^{+} / \mathrm{CD} 27^{+}\right)$lymphocytes, marginal zone $\mathrm{B}$ cells $\left(\mathrm{CD} 19^{+} / \mathrm{CD} 27^{+} / \mathrm{IgM}^{+} / \mathrm{IgD}^{+}\right)$, class-switched memory B cells $\left(\mathrm{CD} 19^{+} / \mathrm{CD} 27^{+} / \mathrm{IgM}^{-} / \mathrm{IgD}^{-}\right)$, and immature $\mathrm{CD} 19^{+} / \mathrm{CD} 21^{\text {low }} \mathrm{B}$ cells.

\section{MATERIALS AND METHODS}

Patients. This study included children with primary humoral immunodeficiencies characterized by presence of circulating B cells and a control group (Table 1). All types of hypogammaglobulinemia were diagnosed according to criteria of the International Union of Immunologic Society (15). Children were selected from $\sim 600$ children referred to our outpatient clinic with recurrent upper respiratory tract infections in whom hypogammaglobulinemia was diagnosed. In the end of 5-y duration study, patients were grouped retrospectively, after longitudinal observation of serum immunoglobulin levels. Patients with hypogammaglobulinemia persistent beyond the 5th year of life were diagnosed as CVID (56 patients), and patients in whom level of immunoglobulins normalized with age were classified as THI (37 patients). In patients classified as SIgAD (39 patients), IgA level remained undetectable during observation period of over $3 \mathrm{y}$. In most children, B-cell subsets were examined only once, although in some children additional studies of B-cell subsets were performed during routine clinical and laboratory follow-up. Children in whom immunodeficiency was excluded formed control group (55 children). This study also included adult patients with CVID (28 patients) and a group of adult healthy subjects (12 controls). Informed consent was obtained from parents of children and adult patients. This study was approved by the Bioethical Committee of the Jagiellonian University.

Determination of lymphocytes phenotype. Peripheral blood mononuclear cells (PBMCs) were isolated from EDTA-treated peripheral blood by standard
Isopaque/Ficoll density gradient and resuspended in PBS solution. It has been shown previously that percentage of B-cell subsets obtained from patients and controls are not significantly altered using whole blood or PBMCs method (27). Cells were incubated for $30 \mathrm{~min}$ at $4^{\circ} \mathrm{C}$ with the following combinations of directly labeled MAb (mAbs): anti-CD19-APC, anti-CD21-PE, and antiIgM-FITC (all purchased from Pharmingen/Becton Dickinson, San Diego, CA) or anti-CD19-APC, anti-IgM-FITC, anti-IgD-PE, and anti-CD27-PECy5 (purchased from Immunotech/Coulter, Marseille, France). Appropriate isotype controls were used in parallel. After two washes, the cells were resuspended in PBS and analyzed by three- and four-color flow cytometry (FACSCanto, Becton Dickinson Immunocytometry Systems, Palo Alto, CA) using FACSDiva v.4.02 software. The list mode data of 50,000 events from PBMCs in a "live gate" mode were acquired. The cells were gated on lymphocytes according to forward (FSC) and side scatter (SSC) parameters. All the results were given as the percentage of $\mathrm{B}$ cells and not as the percentage of lymphocytes or absolute count, because for clinical practice it is easier to use the former as suggested by Paris and EUROclass classifications $(24,26)$.

Statistics. Data were analyzed using the PRISM GraphPad 4 statistical package (GraphPad Software Inc., San Diego, CA). Nonparametric correlation Spearman test (two-tailed) and linear regression were used for analyses of dependencies between particular parameters in studied groups. For unpaired comparisons between the groups two-sided Mann-Whitney $U$ test was used. $p<0.05$ was regarded as statistically significant.

\section{RESULTS}

Total population of memory B cells. In control groups, the level of $\mathrm{CD} 19^{+} / \mathrm{CD} 27^{+}$memory B cells increased with age (correlation between the level of memory B cells and age was significant; Spearman $r=0.43$ ). However, in children with CVID, the level of memory B cells did not increase with age (Spearman $r=-0.37$ ) and the differences between the slopes (linear regression fit) of CVID and control group were statistically significant (Fig. 1A). This difference was more significant in boys than in girls (data not shown). In children with CVID younger than 4-5 y of life, the level of memory B cells was comparable with age-matched controls, but the level of these cells, in contrast to control, did not increase with age; hence, in older children with CVID (between 5- and 18-y old), a significant decrease in the percentage of these cells was observed (Fig. 1D). In children with CVID between 5- and 18 -y old, the level of these cells displayed similar shifts as in adult patients with CVID (Fig. 1D). However, follow-up of several children with CVID revealed that even in some children with initially normal level of memory B cell, a decrease of these cells was observed over time (Fig. 1E).

In children with SIgAD and THI, the level of memory B cells increased with age (Fig. $1 B$ and $C$, Spearman $r=0.37$, Spearman $r=0.35$, respectively) and the differences between the slopes and elevations of lines (linear regression) of patient and control groups were not statistically significant. In SIgAD group and THI group during entire period of hypogamma-

Table 1. Characteristics of patients

\begin{tabular}{|c|c|c|c|c|c|c|}
\hline Disease & $\begin{array}{l}\text { Number } \\
\text { of patients }\end{array}$ & $\begin{array}{l}\text { Mean age at the time of } \\
\text { B-cell subsets examination (y) }\end{array}$ & $\begin{array}{l}\text { Circulating B } \\
\text { cells* }\end{array}$ & $\begin{array}{l}\text { Serum } \operatorname{IgG} \\
\text { level* }\end{array}$ & $\begin{array}{l}\text { Serum IgA } \\
\text { level* }\end{array}$ & $\begin{array}{l}\text { Serum IgM } \\
\text { level* }\end{array}$ \\
\hline CVID & 56 & $7.1 \pm 3.6$ & $\begin{array}{l}\text { Normal }(42) \dagger \text { or } \\
\text { decreased }(14)\end{array}$ & Decreased & Decreased & $\begin{array}{l}\text { Normal (21) or } \\
\text { decreased (35) }\end{array}$ \\
\hline SIgAD & 39 & $6.5 \pm 3.8$ & Normal & Normal & Absent & Normal \\
\hline THI & 37 & $2.04 \pm 1$ & Normal & Decreased & $\begin{array}{l}\text { Normal (13) or } \\
\quad \text { decreased (24) }\end{array}$ & Normal \\
\hline
\end{tabular}

\footnotetext{
* The level of circulating B cells and immunoglobulin levels are given individually with the reference to normal ranges for age.
}

$\dagger$ Number of patients. 
A

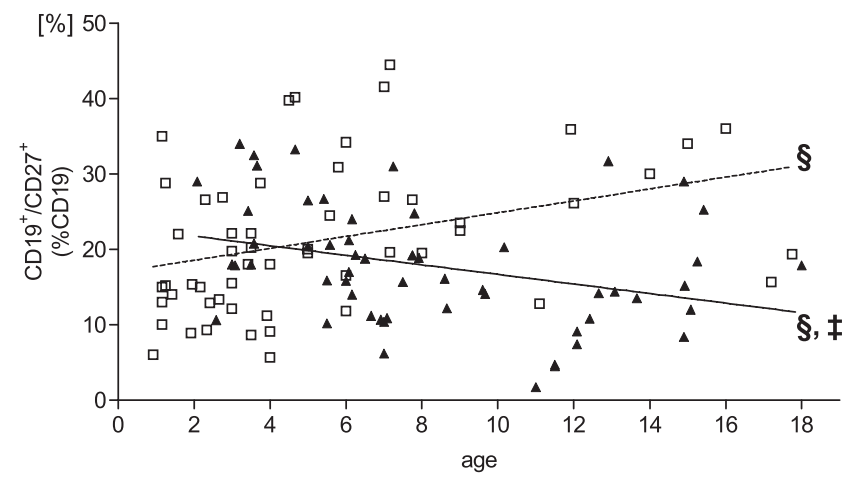

C

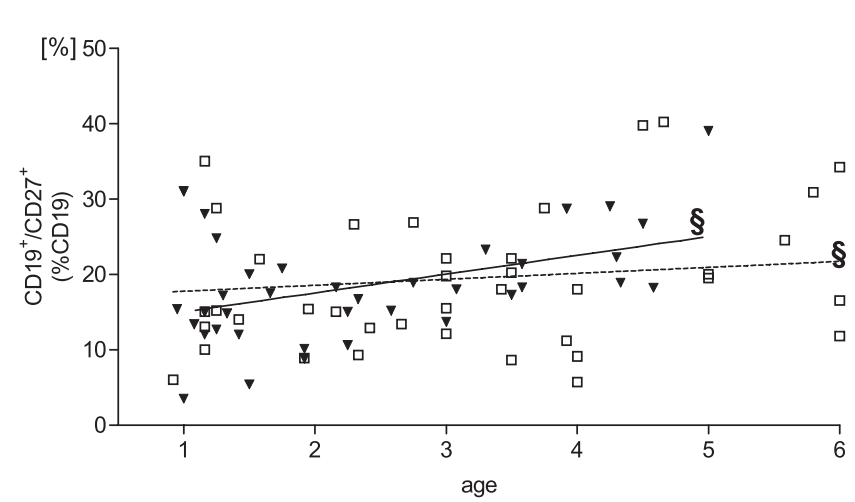

E

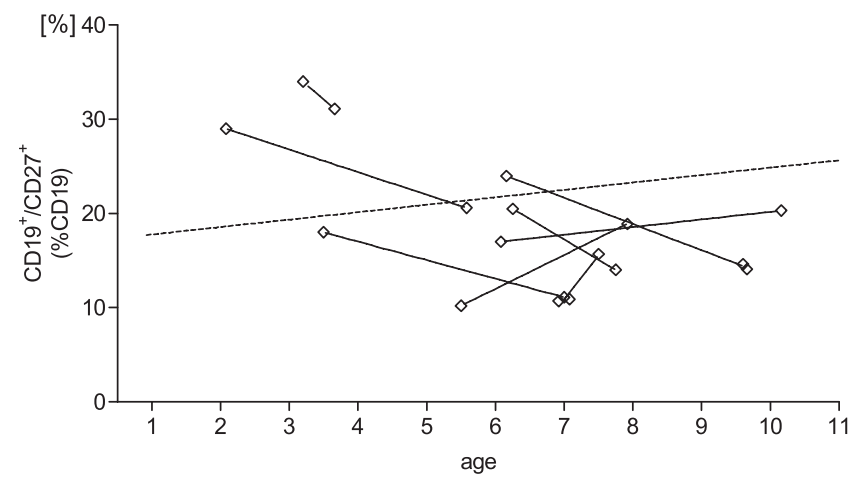

B

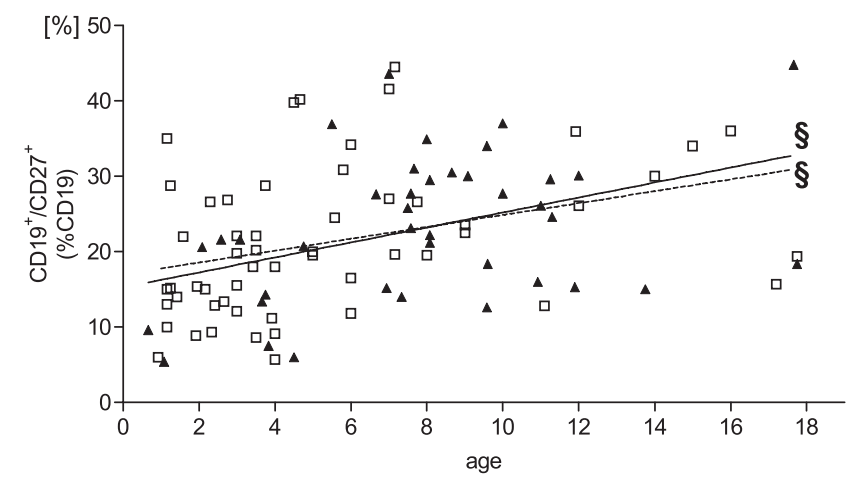

D

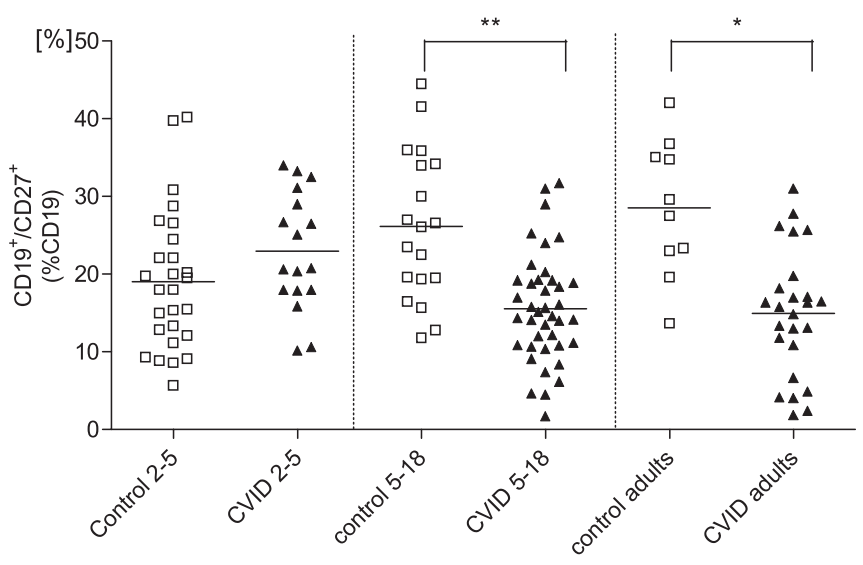

F

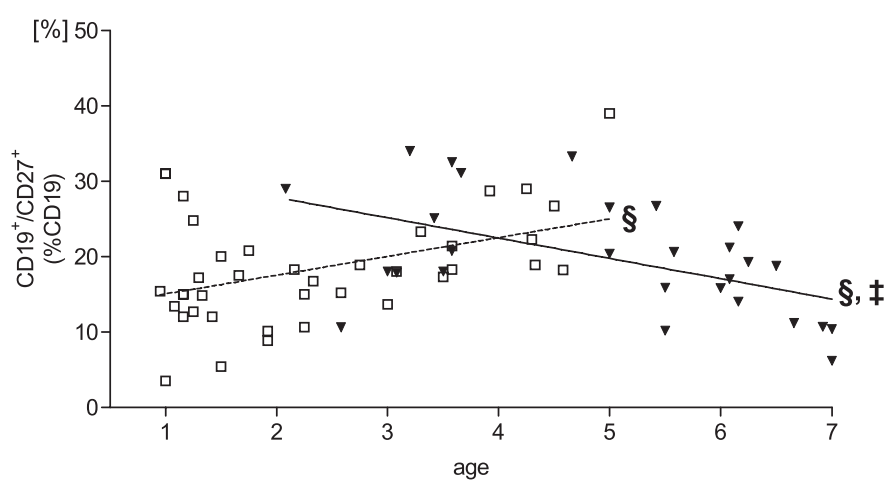

Figure 1. The level of memory cells. Isolated PBMCs were labeled with anti-CD19-APC/CD27-PE-Cy5 mAbs or relevant isotype controls and analyzed by flow cytometry. The results are calculated as the percentage of B lymphocytes. Correlation between the level of memory B cells and age in children with $A$, CVID (一), B, SIgAD (-), C, THI (-), and age-matched controls (-) [patients—black triangles, control—white squares]. D, Comparison of the level of memory B cells between age-matched controls and children with CVID 2- to 5-y old, children with CVID 5- to 18-y old, and adults with CVID. E, Analysis of memory B cells in several children with CVID during follow-up (-) and control (-) [CVID-black triangles, control-white squares]. $F$, Correlation of the level of memory B cells and age in CVID (-) and THI (-) children [CVID—black triangles, THI—white squares]. $\$ p<0.05$ (for Spearman's $r$ correlation values), $\ddagger p<0.002$ (linear regression), $* p<0.001$ (Mann-Whitney $U$ test), ${ }^{* *} p<0.0001$ (Mann-Whitney $U$ test).

globulinemia, the level of memory B cells was comparable with age-matched controls (Fig. $1 B$ and $C$ ). Comparison of the level of memory B cells in CVID and THI in age subgroups (1- to 7-y old) (Fig. $1 F$ ) revealed the profound difference between the slopes (linear regression fit) of CVID and THI group $(p<0.0001)$.

Marginal zone B cells. The age-dependent increase in the level of marginal zone B cells $\left(\mathrm{CD} 19^{+} / \mathrm{CD} 27^{+} / \mathrm{IgM}^{+} / \mathrm{IgD}^{+}\right)$ in control group was observed. The decrease in the level of these cells observed in some patients with CVID concomitant with low levels of memory B cell. In patients with SIgAD and THI, there were no differences in the level of these cells when compared with the appropriate controls (data not shown).

Class-switched memory B cells. The level of class-switched memory B cells $\left(\mathrm{CD} 19^{+} / \mathrm{CD} 27^{+} / \mathrm{IgM}^{-} / \mathrm{IgD}^{-}\right)$was presented as the percentage of total B cells (Fig. 2) and of memory B cells (Fig. 3). In control group, regardless of manner of data presentation, the level of class-switched memory B cells 
A

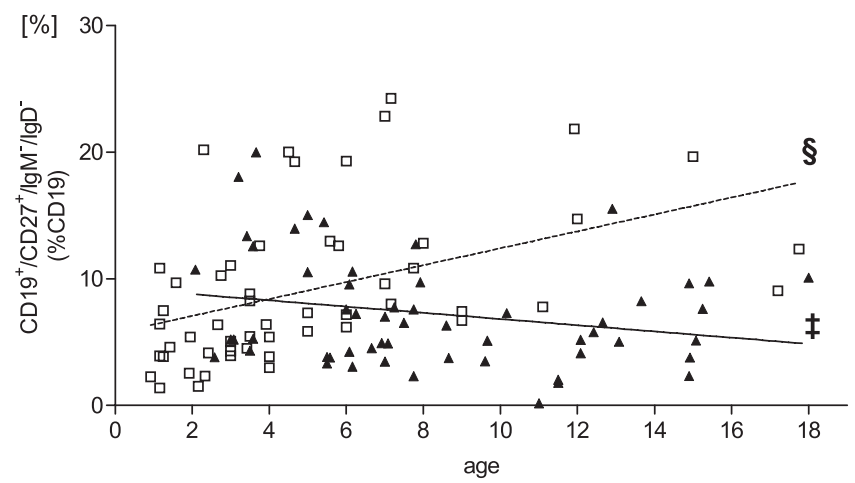

C

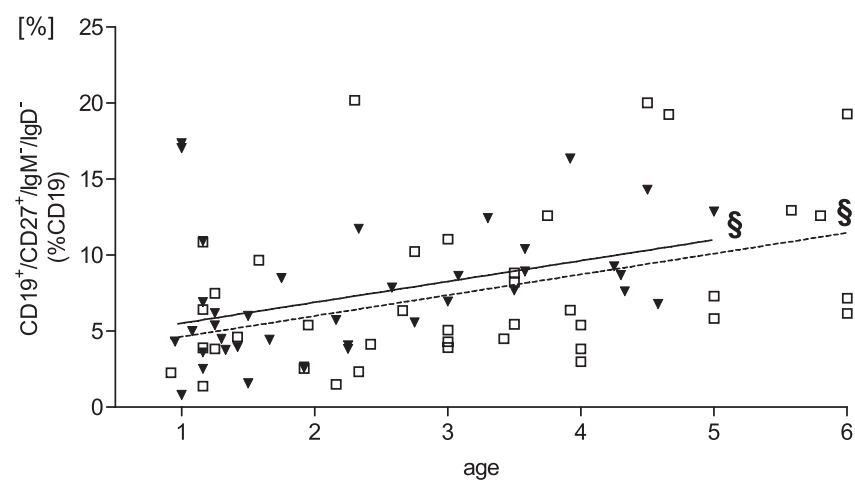

B

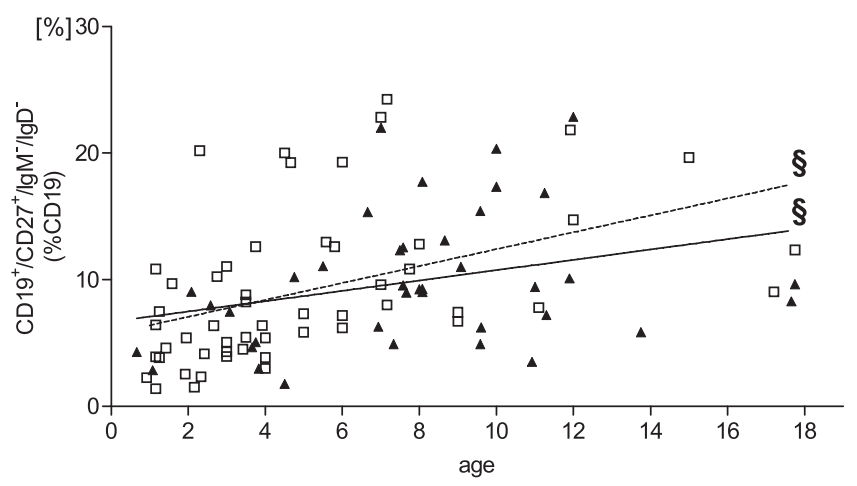

D

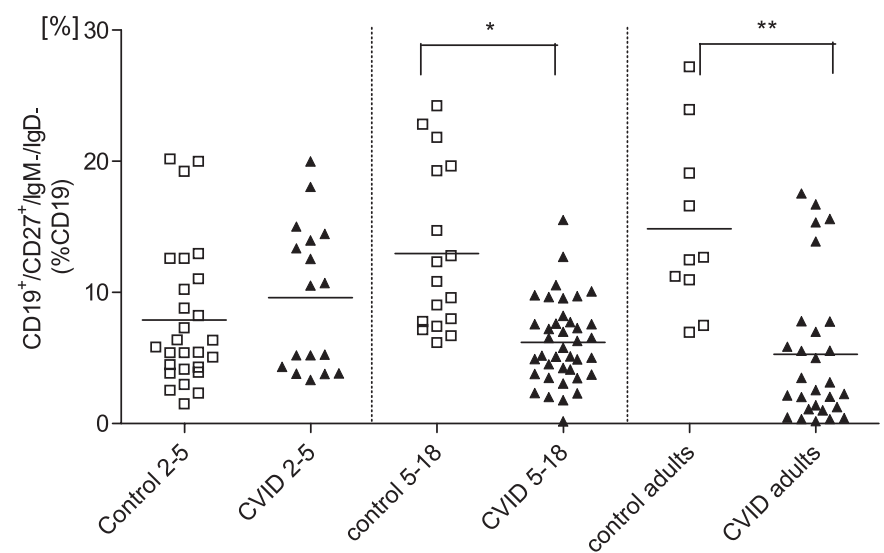

Figure 2. Class-switched memory B cells calculated as percentage of B cells. Isolated PBMCs were labeled with anti-CD19-APC/CD27-PE-Cy5/IgM-FITC/ IgD-PE mAbs or relevant isotype controls. Correlation between the level of class-switched memory B cells and age in groups of children with A, CVID (-), $B$, SIgAD (-), $C$, THI (-), and age-matched controls (-) [patients-black triangles, control—white squares]. $D$, comparison of the level of class-switched memory B cells between children with CVID 2- to 5-y old, children with CVID 5- to 18-y old, adults with CVID and age-matched controls. §p $<0.05$ (for Spearman's $r$ correlation values), $\neq p<0.002$ (linear regression), ${ }^{*} p<0.001$ (Mann-Whitney $U$ test), $* * p<0.0001$ (Mann-Whitney $U$ test).

increased with age (Spearman $r=0.57$ and Spearman $r=$ 0.54 , respectively). However, in children with CVID the level of these cells did not increased with age (correlation was not significant, Figs. $2 A$ and $3 A$ ). These differences were more significant in group of boys than in group of girls (data not shown). The differences between the slopes (linear regression fit) of CVID and control group were statistically significant (for data presented as percentage of B cells-Fig. 2A, and memory B cells-Fig. $3 A$ ). In younger children with CVID (2to 5-y old), the differences in the level of class-switched memory B cells in comparison with controls were not significant. However, in older children (between 5 and 18) the level of these cells was markedly lower than in age-matched controls (Fig. 2D-the percentage of class-switched memory B cells within the entire B-cell population; Fig. $3 D$-the percentage of class-switched memory B cells within memory B-cell subset). Abnormalities in the level of switched memory B cells in older children with CVID were similar to those seen in adult patients with CVID (Figs. $2 D$ and $3 D$ ). However, follow-up of several children with CVID revealed that even in some children with initially normal level of class-switched memory B cell, a decrease of these cells was observed over time (data not shown).
In children with SIgAD, class-switched memory B cells within the entire B-cell population increased with age (Spearman $r=0.36$ ), and the differences between the slopes and elevations of lines (linear regression) of SIgAD and control groups were not statistically significant (Fig. 2B). However, the level of these cells calculated as percentage of memory B cells displayed similar abnormalities as seen in children with CVID, as these cells did not increase with age and the differences between the slopes (linear regression fit) of SIgAD and control group were statistically significant (Fig. 3B).

In children with THI, the level of class-switched memory B cells increased with age (Fig. $2 C, \mathrm{CD} 19^{+} / \mathrm{CD} 27^{+} / \mathrm{IgM}^{-} / \mathrm{IgD}^{-}$ within B cells-Spearman $r=0.43$; Fig. $3 C$, CD $19^{+} / \mathrm{CD} 27^{+} /$ $\mathrm{IgM}^{-} / \mathrm{IgD}^{-}$within memory B cells-Spearman $r=0.37$ ), and the differences between the slopes and elevations of lines (linear regression) of THI and control groups were not statistically significant. In THI group, the level of class-switched memory B cells was comparable with controls during entire period of disease, regardless the way of percentage calculation (Figs. $2 C$ and $3 C$ ). Comparison of the level of class-switched memory B cells in CVID and THI in age subgroups (1- to 7-y old) revealed statistically significant differences between the slopes (linear regression fit) of CVID and THI group (data not shown). 
A

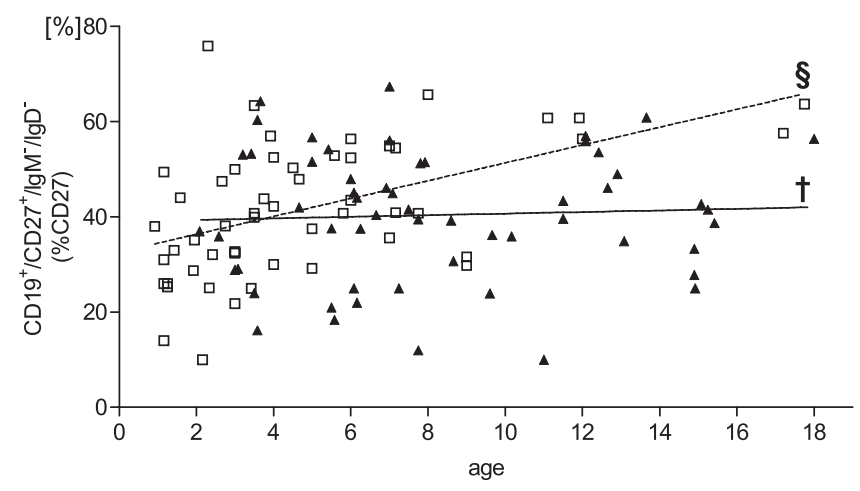

C

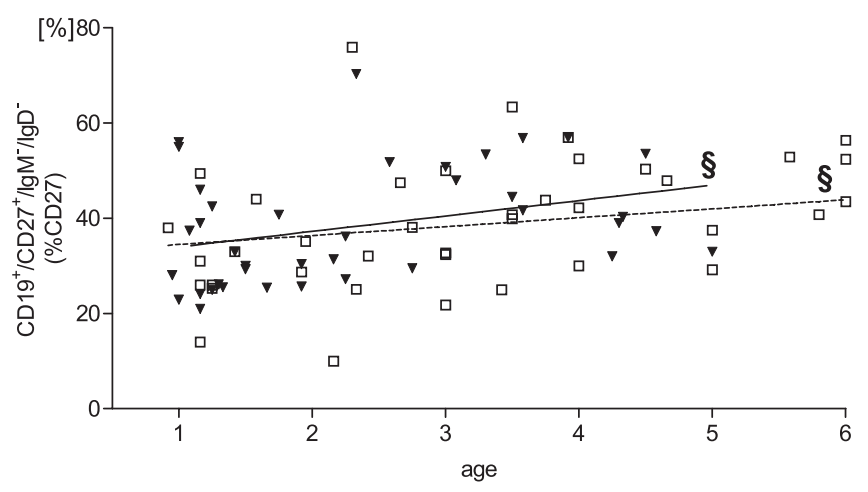

B

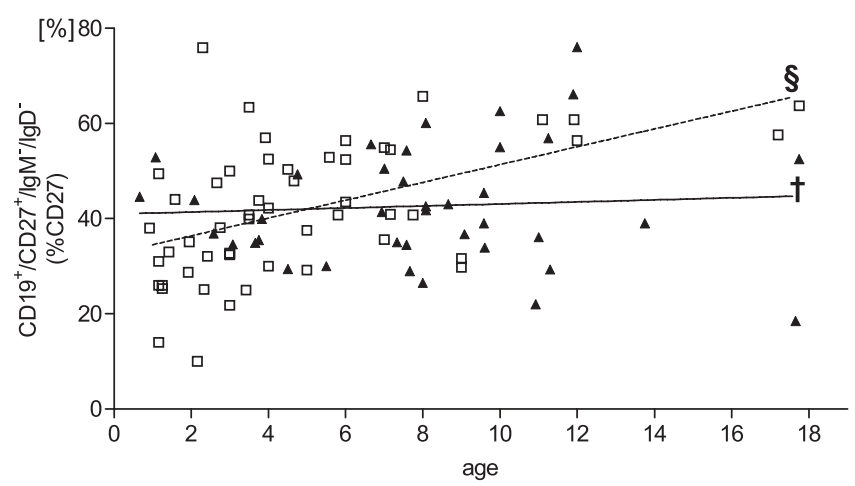

D

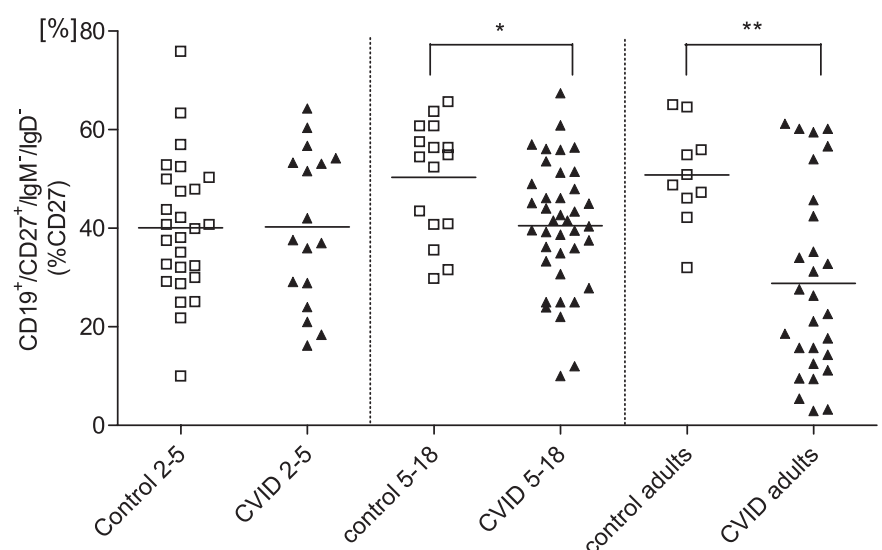

Figure 3. Class-switched memory B cells calculated as percentage of memory B cells. Isolated PBMCs were labeled with anti-CD19-APC/CD27-PE-Cy5/ IgM-FITC/IgD-PE mAbs or relevant isotype controls. Correlation between the level of class-switched memory B cells and age in groups of children with $A$, CVID (一), B, SIgAD (—), C, THI (—), and age-matched controls (—) [patients—black triangles, control—white squares]. $D$, comparison of the level of class-switched memory B cells between age-matched controls and children with CVID 2- to 5-y old, children with CVID 5- to 18-y old, and adults with CVID. $\$ p<0.05$ (for Spearman's $r$ correlation values), $\dagger p<0.02$ (linear regression), ${ }^{*} p<0.02$ (Mann-Whitney $U$ test), $* * p<0.005$ (Mann-Whitney $U$ test).

The level of CD21 ${ }^{\text {low }} \mathrm{B}$ cells. In all patient groups, correlation between the level of $\mathrm{CD} 21^{\text {low }} \mathrm{B}$ cells and age was not significant. The differences between the slopes and elevations of lines of patient and control groups were also not statistically significant (Fig. 4A-C). In children with CVID, the level of $\mathrm{CD} 21^{\text {low }}$ cells did not display shifts seen in adult patients, as there was no elevation of $\mathrm{CD} 21^{\text {low }}$ cells in children when compared with age-matched controls (Fig. 4D).

\section{DISCUSSION}

A number of studies have recently described abnormalities of B-cell subpopulations in the blood of patients with CVID (25-27,35,37). However, most of these studies were mainly focused on adult patients with CVID. There are little data concerning an early-onset patients with CVID (35) and no studies examining subpopulations of B cells in SIgAD and THI were performed. This study focused on changes with age in the B-cell compartment in the blood of children with CVID, symptomatic SIgAD, and THI.

The most common aberration in patients with CVID is the reduction of memory $\mathrm{B}$ cells $\left(\mathrm{CD} 19^{+} / \mathrm{CD} 27^{+}\right)$and classswitched memory B cells $\left(\mathrm{CD}_{1} 9^{+} / \mathrm{CD} 27^{+} / \mathrm{IgD}^{-} / \mathrm{IgM}^{-}\right)$, indicating a disturbed germinal center function. Thus, classswitched memory $\mathrm{B}$ cells have been chosen by all classification systems as the primary classifying parameter (24-26). All these classification schemes are based on values established in adults. Yet, there are some limitations in application of these classifications to pediatric patients with CVID, because of changes in the frequency in the B-cell subsets with age. Memory B cells are undetectable in cord blood, slowly increase during the first year of life, and reach $10-20 \%$ of the $\mathrm{B}$ cells at 2 nd year of life in healthy children (31). In adult healthy individuals, $30-60 \%$ of B cells are memory B cells. Approximately half of these cells are class-switched memory B cells (31). Because of the fact that levels of B-cell subsets are age-dependent, these classifications are of limited use in pediatric patients, as the level of class-switched memory B cells in some control children younger than $10 \mathrm{y}$ is below normal ranges established for adult healthy subjects (below $6.5 \%$ of B cells). Hence, pediatric groups need to be analyzed according to the age-matched control group. Our data obtained in children with CVID are slightly different from that in adult patients with CVID. First, it seems that children with CVID develop abnormalities in B-cell compartment similar to those observed in adult patients with CVID with time. In children with CVID younger than 4- to 5-y old, the B-cell compartment was comparable with the age-matched control group; however, in some younger children, later classified as having 
A

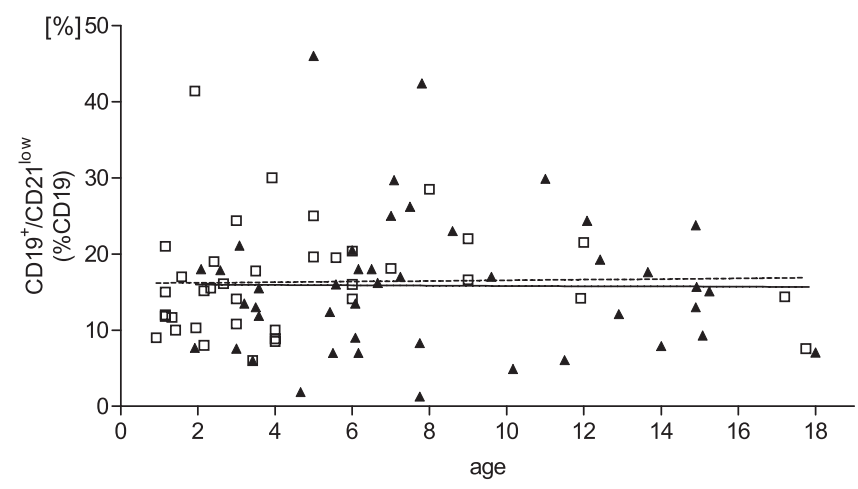

C

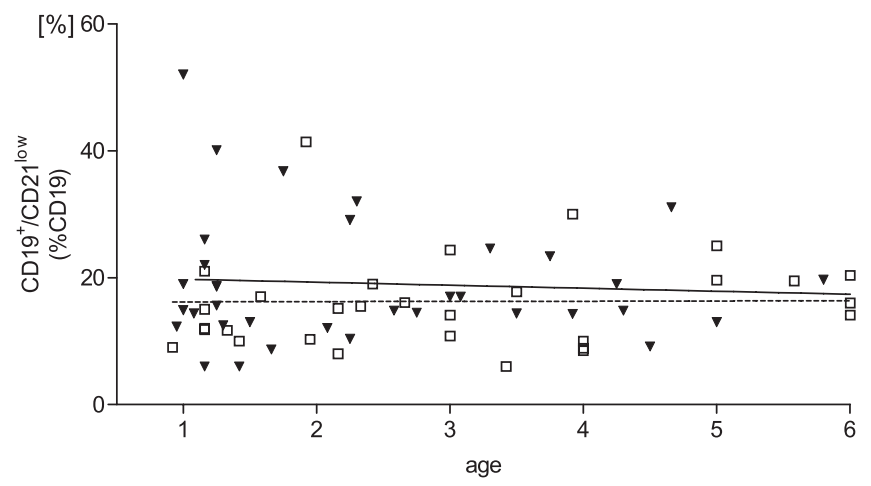

B

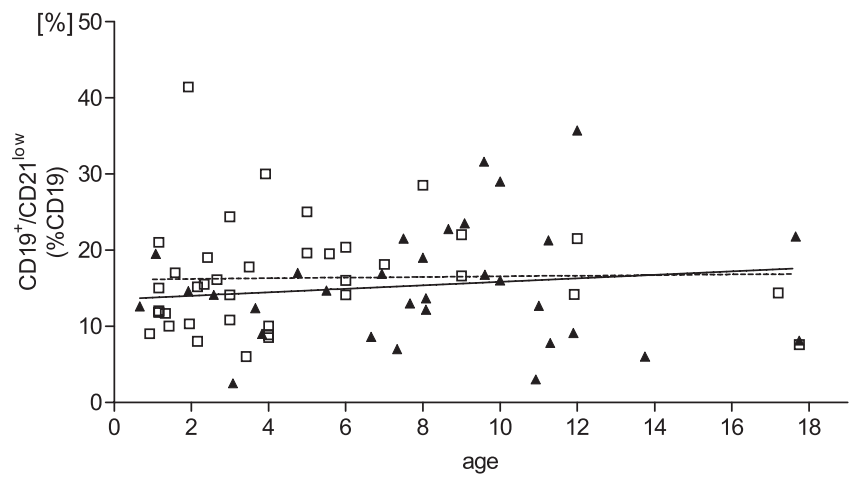

D

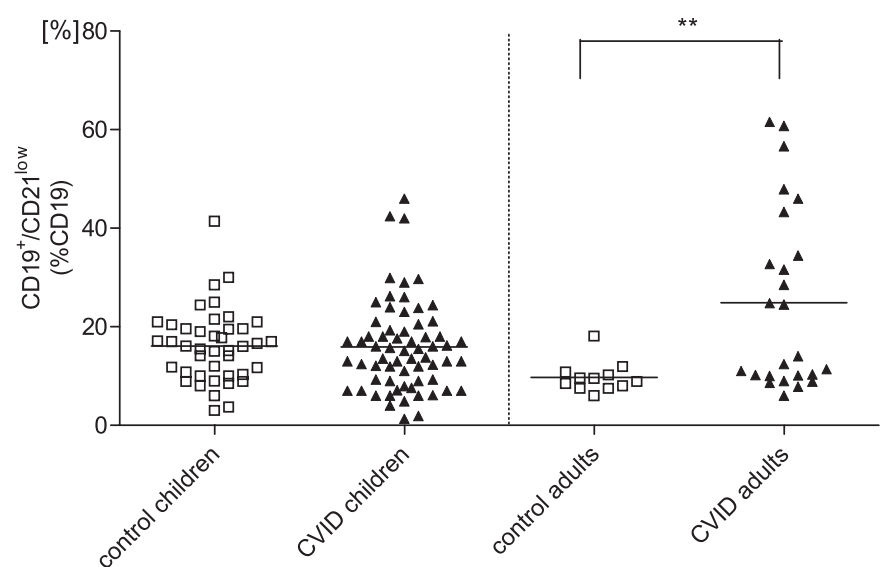

Figure 4. The percentage of immature $\mathrm{CD} 21^{\text {low }} \mathrm{B}$ cells. Isolated PBMCs were labeled with anti-CD19-APC/CD21-PE mAbs or relevant isotype controls. Results are shown as the percentage of $\mathrm{CD} 19^{+} / \mathrm{CD} 21^{\text {low }}$ cells among B cells. Correlation between the level of these cells and age in patients with $A$, CVID ( - ), $B$, SIgAD (-), C, THI (-), and control subjects (-) [patients-black triangles, control—white squares]. D, Comparison of the level of CD21 ${ }^{\text {low }} \mathrm{B}$ cells between children with CVID and adults with CVID. ${ }^{* *} p<0.005$ (Mann-Whitney $U$ test).

CVID, with initially normal percentage of memory B-cell subsets, a decrease of these cells was observed during followup. It seems that decreased percentage of memory B cells is rather connected with increasing number of entire $\mathrm{CD} 19^{+}$ $\mathrm{B}$-cell population without parallel increase of the level of memory B-cells. Because the level of memory B-cell subsets in children with CVID, in contrast to control, did not increase with age, and children older than 5 y of age displayed characteristics of adult patients with CVID: decrease in the level of memory B cells, and in class-switched memory B cells, whereas, no difference in the level of immature B cells was seen. The latter is consistent with the fact that adult patients with CVID with increased level of CD2 $1^{\text {low }} \mathrm{B}$ cells had a significant delayed onset and diagnosis than other patients with CVID (26). Furthermore, it has been revealed that TACI deficiency is not linked to a specific B-cell phenotype, as TACI is not involved in B-cell differentiation up to the stage of memory B cells (26). This is also consistent with our findings, as none of patients with CVID presenting low levels of memory and class-switched memory B cells had mutation in TACI. However, in this study TACI mutations were excluded only in part of patients (data not shown).

To our knowledge, this is the first demonstration of memory $B$ cells abnormalities in SIgAD. Interestingly, changes in B-cell subsets observed in SIgAD were only partly similar to
CVID. In patients with SIgAD, the level of memory B cells was similar to control group, whereas the subset of classswitched memory B cells within a population of memory B cells displayed abnormalities similar to those seen in children with CVID. Some similarities between behavior of B-cell compartment in CVID and symptomatic SIgAD may provide additional evidence for the linkage of these entities $(19,21,23)$. Patients with SIgAD in whom the level of class-switched memory B cells has been profoundly decreased, require further observation as to whether they may develop CVID. However, as yet, there are no studies indicating the association of decreased level of these cells with the risk of CVID development.

Subsequently, we addressed the question of whether there were any further differences concerning B-cell subpopulations in children with THI. We found that in contrast to patients with CVID and SIgAD, in THI children B-cell compartment is unchanged compared with age-matched control group. The levels of B-cell subsets in children with THI were normal during entire period of hypogammaglobulinemia. It corroborates the hypothesis that defect in immunoglobulin production in children with THI is rather connected with an inappropriate immunoregulation than with disturbance in development of particular subpopulation of B cells. 
Symptomatic THI and an early-onset CVID may have overlapping clinical features, especially in children younger than 5-6 y. The positive antibody response to vaccines in the former was used for differential diagnosis of these entities. However, recent evidence indicates that $\sim 20 \%$ of patients with CVID have positive response to both protein and polysaccharide vaccines and $\sim 58 \%$ have single positive antibody response after immunization (38). Therefore, the positive response to vaccines is not contradictory to the diagnosis of CVID $(38,39)$. We demonstrated that in children with CVID, in contrary to THI, the development of memory B-cell subsets is disturbed. Hence, the persistence over the time of low levels of memory B-cell subsets in some children with hypogammaglogulinemia and the presence of circulating B lymphocytes may predict the development of CVID and be helpful in establishment of CVID diagnosis.

\section{REFERENCES}

1. Stagg AJ, Funauchi M, Knight SC, Webster AD, Farrant J 1994 Failure in antigen responses by $\mathrm{T}$ cells from patients with common variable immunodeficiency (CVID). Clin Exp Immunol 96:48-53

2. Fischer MB, Wolf HM, Hauber I, Eggenbauer H, Thon V, Sasgary M, Eibl MM 1996 Activation via the antigen receptor is impaired in T cells, but not in B cells from patients with common variable immunodeficiency. Eur J Immunol 26:231-237

3. Boncristiano M, Majolini MB, D'Elios MM, Pacini S, Valensin S, Ulivieri C, Amedei A, Falini B, Del Prete G, Telford JL, Baldari CT 2000 Defective recruitment and activation of ZAP-70 in common variable immunodeficiency patients with T cell defects. Eur J Immunol 30:2632-2638

4. Jaffe JS, Strober W, Sneller MC 1993 Functional abnormalities of CD81 T cells define a unique subset of patients with common variable immunodeficiency. Blood 82:192-201

5. Kowalczyk D, Mytar B, Zembala M 1997 Cytokine production in transient hypogammaglobulinaemia and isolated IgA deficiency. J Allergy Clin Immunol 100:556-562

6. Denz A, Eibel H, Illges H, Kienzle G, Schlesier M, Peter HH 2000 Impaired up-regulation of CD86 in B cells of "type A" common variable immunodeficiency patients. Eur J Immunol 30:1069-1077

7. Eisenstein EM, Strober W 1995 Evidence for a generalized signaling abnormality in B cells from patients with common variable immunodeficiency. Adv Exp Med Biol 371B:699-704

8. van Zelm MC, Reisli I, van der Burg M, Castano D, van Noesel CJ, van Tol MJ, Woellner C, Grimbacher B, Patino PJ, van Dongen JJ, Franco JL 2006 An antibodydeficiency syndrome due to mutations in the CD19 gene. N Engl J Med 354:19011912

9. Goldacker S, Warnatz K 2005 Tackling the heterogeneity of CVID. Curr Opin Allergy Clin Immunol 5:504-509

10. Grimbacher B, Hutloff A, Schlesier M, Glocker E, Warnatz K, Drager R, Eibel H, Fischer B, Schaffer A, Mages HW, Kroczek RA, Peter HH 2003 Homozygous loss of ICOS is associated with adult-onset common variable immunodeficiency. Nat Immunol 4:261-268

11. Salzer U, Chapel HM, Webster AD, Pan-Hammarstrom Q, Schmitt-Graeff A, Schlesier M, Peter HH, Rockstroh JK, Schneider P, Schaffer AA, Hammarstrom L, Grimbacher B 2005 Mutations in TNFRSF13B encoding TACI are associated with common variable immunodeficiency in humans. Nat Genet 37:820-828

12. Castigli E, Wilson SA, Garibyan L, Rachid R, Bonilla F, Schneider L, Geha RS 2005 TACI is mutant in common variable immunodeficiency and IgA deficiency. Nat Genet 37:829-834

13. Pan-Hammarström Q, Salzer U, Du L, Björkander J, Cunningham-Rundles C, Nelson DL, Bacchelli C, Gaspar HB, Offer S, Behrens TW, Grimbacher B, Hammarström L 2007 Reexamining the role of TACI coding variants in common variable immunodeficiency and selective IgA deficiency. Nat Genet 39:429-430

14. Castigli E, Wilson S, Garibyan L, Rachid R, Bonilla F, Schneider L, Morra M, Curran J, Geha R 2007 Reexamining the role of TACI coding variants in common variable immunodeficiency and selective IgA deficiency. Nat Genet 39:430-431

15. Geha RS, Notarangelo LD, Casanova JL, Chapel H, Conley ME, Fischer A, Hammarström L, Nonoyama S, Ochs HD, Puck JM, Roifman C, Seger R, Wedgwood J 2007 Primary immunodeficiency diseases: an update from the International Union of Immunological Societies Primary Immunodeficiency Diseases Classification Committee. J Allergy Clin Immunol 120:776-794

16. Cunningham-Rundles C 2001 Physiology of IgA and IgA deficiency. J Clin Immunol 21:303-309
17. Marconi M, Plebani A, Avanzini MA, Maccario R, Pistorio A, Duse M, Striuga M, Monafo V 1998 IL-10 and IL-4 co-operate to normalize in vitro IgA production in IgA-deficient patients. Clin Exp Immunol 112:528-532

18. Kowalczyk D, Macura-Biegun A, Zembala M 2006 The expression of CD40 on monocytes of children with primary humoral immunodeficiencies. Pediatr Res 59:816-819

19. Johnson ML, Keeton LG, Zhu Z-B, Volanakis JE, Cooper MD, Schroeder JR 1997 Age-related changes in serum immunoglobulins in patients with familial $\operatorname{IgA}$ deficiency and common variable immunodeficiency (CVID). Clin Exp Immunol 108:477-483

20. Espanol T, Catala M, Hernandez M, Caragol I, Bertran JM 1996 Development of a common variable immunodeficiency in IgA deficient patients. Clin Immunol Immunopathol 80:333-335

21. Gutierrez MG, Kirkpatrick CH 1997 Progressive immunodeficiency in a patient with IgA deficiency. Ann Allergy Asthma Immunol 79:297-301

22. Seligmann M, Aucouturier P, Danon F, Preud'Homme JL 1991 Changes in serum immunoglobulin patterns in adults with common variable immunodeficiency. Clin Exp Immunol 84:23-27

23. Vorechovsky I, Zetterquist H, Paganelli R, Koskinen S, Webster AD, Bjorkander J, Smith CI, Hammarstrom L 1995 Family and linkage study of selective IgA deficiency and common variable immunodeficiency. Clin Immunol Immunopathol 77:185-192

24. Piqueras B, Lavenu-Bombled C, Galicier L, Bergeron-van der Cruyssen F, Mouthon L, Chevret S, Debré P, Schmitt C, Oksenhendler E 2003 Common variable immunodeficiency patient classification based on impaired B cell memory differentiation correlates with clinical aspects. J Clin Immunol 23:385-400

25. Warnatz K, Denz A, Drager R, Braun M, Groth C, Wolff-Vorbeck G, Eibel H, Schlesier M, Peter HH 2002 Severe deficiency of switched memory B cells $(\mathrm{CD} 27(+) \operatorname{IgM}(-) \operatorname{IgD}(-))$ in subgroups of patients with common variable immunodeficiency: a new approach to classify a heterogeneous disease. Blood 99:15441551

26. Wehr C, Kivioja T, Schmitt C, Ferry B, Witte T, Eren E, Vlkova M, Hernandez M, Detkova D, Bos PR, Poerksen G, von Bernuth H, Baumann U, Goldacker S, Gutenberger S, Schlesier M, Bergeron-van der Cruyssen F, Le Garff M, Debré P, Jacobs R, Jones J, Bateman E, Litzman J, van Hagen PM, Plebani A, Schmidt RE, Thon V, Quinti I, Espanol T, Webster AD, Chapel H, Vihinen M, Oksenhendler E, Peter HH, Warnatz K 2008 The EUROclass trial: defining subgroups in common variable immunodeficiency. Blood 111:77-85

27. Ferry BL, Jones J, Bateman EA, Woodham N, Warnatz K, Schlesier M, Misbah SA, Peter HH, Chapel HM 2005 Measurement of peripheral B cell subpopulations in common variable immunodeficiency (CVID) using a whole blood method. Clin Exp Immunol 140:532-539

28. Shi Y, Agematsu K, Ochs HD, Sugane K 2003 Functional analysis of human memory B-cell subpopulations: $\operatorname{IgD}+\mathrm{CD} 27+\mathrm{B}$ cells are crucial in secondary immune response by producing high affinity IgM. Clin Immunol 108:128-137

29. Klein U, Rajewsky K, Kuppers R 1998 Human immunoglobulin (Ig) M+IgD+ peripheral blood B cells expressing the CD27 cell surface antigen carry somatically mutated variable region genes: CD27 as a general marker for somatically mutated (memory) B cell. J Exp Med 188:1679-1689

30. Weller S, Braun MC, Tan BK, Rosenwald A, Cordier C, Conley ME, Plebani A, Kumararatne DS, Bonnet D, Tournilhac O, Tchernia G, Steiniger B, Staudt LM, Casanova JL, Reynaud CA, Weill JC 2004 Human blood IgM "memory" B cells are circulating splenic marginal zone B cells harboring a prediversified immunoglobulin repertoire. Blood 104:3647-3654

31. Kruetzmann S, Rosado MM, Weber H, Germing U, Tournilhac O, Peter HH, Berner R, Peters A, Boehm T, Plebani A, Quinti I, Carsetti R 2003 Human immunoglobulin M memory B cells controlling Streptococcus pneumoniae infections are generated in the spleen. J Exp Med 197:939-945

32. Buckley RH 2004 Pulmonary complications of primary immunodeficiencies. Paediatr Respir Rev 5:S225-S233

33. Agematsu K, Futatani T, Hokibara S, Kobayashi N, Takamoto M, Tsukada S, Suzuki H, Koyasu S, Miyawaki T, Sugane K, Komiyama A, Ochs HD 2002 Absence of memory B cells in patients with common variable immunodeficiency. Clin Immunol 103:34-42

34. Salzer U, Grimbacher B 2006 Common variable immunodeficiency: the power of co-stimulation. Semin Immunol 18:337-346

35. Brouet JC, Chedeville A, Fermand JP, Royer B 2000 Study of the B cell memory compartment in common variable immunodeficiency. Eur J Immunol 30:2516-2520

36. Ko J, Radigan L, Cunningham-Rundles C 2005 Immune competence and switched memory B cells in common variable immunodeficiency. Clin Immunol 116:37-41

37. Jacquot S, Macon-Lemaitre L, Paris E, Kobata T, Tanaka Y, Morimoto C, Schlossman SF, Tron F 2001 B cell co-receptors regulating T cell-dependent antibody production in common variable immunodeficiency: CD27 pathway defects identify subsets of severely immuno-compromised patients. Int Immunol 13:871-876

38. Sánchez-Ramón S, Radigan L, Yu JE, Bard S, Cunningham-Rundles C 2008 Memory B cells in common variable immunodeficiency: clinical associations and sex differences. Clin Immunol 128:314-321

39. Goldacker S, Draeger R, Warnatz K, Huzly D, Salzer U, Thiel J, Eibel H, Schlesier M, Peter HH 2007 Active vaccination in patients with common variable immunodeficiency (CVID). Clin Immunol 124:294-303 